\title{
THE BASICS OF MUSEUM PEDAGOGY COURSE - A CONTRIBUTION TO THE CURRENT CONCEPTION OF THE COMPETENCE MODEL OF MUSEUM EDUCATORS IN THE CZECH REPUBLIC
}

\section{TOMÁŠ DROBNÝ - PAVLA VYKOUPILOVÁ}

\section{ABSTRACT/ABSTRAKT:}

The article is dealing with creation of an education offer for museum educators after emergence of the Methodical Centre of Museum Pedagogy. In 2012, the first run of the Basics of Museum Pedagogy course was prepared, which offered a two-semester programme composed of nine lectures including theoretical and practical training of educational workers in memory institutions. During existence of the Basics of Museum Pedagogy course, the perception of the educational role of cultural institutions underwent a significant change. In the fall of 2016, the professional qualification of museum educators was recognized and in January 2018 the profession of an educator in culture appeared for the first time in Czech labourlaw provisions. The article is looking back at the six-year-long existence of the course at a turning point where a new accredited Museum Educator course is being prepared in compliance with defined professional standards and new labour-law provisions.

Kurz Základy muzejní pedagogiky - příspěvek $k$ aktuálnímu pojetí kompetenčního modelu muzejního edukátora v České republice

Článek pojednává o vytvoření vzdělávací nabídky pro muzejní edukátory po vzniku Metodického centra muzejní pedagogiky. $\mathrm{V}$ roce 2012 byl připraven první běh kurzu Základy muzejní pedagogiky, který nabídl dvousemestrální program devíti přednášek zahrnujících teoretickou i praktickou přípravu edukačních pracovníků v pamětových institucích. $V$ průběhu existence kurzu Základy muzejní pedagogiky nastala významná změna ve vnímání vzdělávací role kulturních institucí. Na podzim 2016 byla uznána profesní kvalifikace muzejního edukátora a v lednu 2018 se poprvé v českých pracovně-právních předpisech objevila profese edukátora v kultuře. Článek je ohlédnutím za šestiletou existencí kurzu v přelomovém okamžiku přípravy nového akreditovaného kurzu muzejního edukátorav souladu se stanovenými profesními standardy a novými pracovně-právními předpisy.

\section{KEYWORDS/ KLÍČOVÁ SLOVA:}

museum pedagogy - educator in culture - museum educator Methodical Centre of Museum Pedagogy - professional training and education - accredited education programme muzejní pedagogika - edukátor $v$ kultuře - muzejní edukátor Metodické centrum muzejní pedagogiky - profesní príprava a vzdělání - akreditovaný vzdělávací program

https://doi.org/10.5817/MuB2018-1-4

1. Preparation of the education of museum pedagogues in the Methodical Centre of Museum Pedagogy

Museum pedagogy already has a hundred-year-long tradition in the Czech museum culture. ${ }^{1}$ However, this discipline entered the second decade of the 21st century without any clearly profiled competence model of the profession of a museum educator. The transformations of museum culture in the Czech society lagged behind the standards of museum work abroad. ${ }^{2}$ In 2004, the Committee for Public Relations and Museum Pedagogy was constituted within the scope of the Czech Association of Museums and Galleries. In one of its sessions in 2009 already, the Committee set an objective to prepare a Course in Museum

\footnotetext{
1 See JAGOŠOVÁ, Lucie and Lenka MRÁZOVÁ. Tradition of museum pedagogy in the Czech Republic and the role of Brno museology in its development. Museologica Brunensia [online]. 2015, vol. 4, no. 2, p. 61 [accessed 2018-06-01]. Available from www: < https://digilib.phil.muni. $\mathrm{cz} /$ bitstream/handle/11222.digilib/134749/2 MuseologicaBrunensia_4-2015-2_11. pdf? sequence $=1>$

2 Lucie Jagošová and Otakar Kirsch remind us that at the beginning of the 21st century „[...] many museums did not yet accept their educational role in the society, where education was regarded as an important part of museum activities but it was not equal to the other museum functions." JAGOŠOVÁ, Lucie and Otakar KIRSCH et al. Muzejní profese a veřejnost 1 . Nástin historie a současnosti vzájemných vztahů muzeí a jejich publika [online]. Brno: Masarykova univerzita, Filozofická fakulta, Ústav archeologie a muzeologie, 2016, p. 49 [accessed 2018-06-01]. Available from www: <http://archeo-muzeo.phil.muni.cz/ media/3056324/muzejni_profese_a_verejnost. pdf $>$.
} 
Pedagogy. ${ }^{3}$ The emergence of methodical centres brought a new impulse on the way both to gaining recognition for the new (revived) profession within the organisation structure of museums and to its implementation into labour-law provisions. The Methodical Centre of Museum Pedagogy, which operates within the scope of the Moravian Museum, is targeted at interconnection of the knowledge from the academic sphere and the approaches used in the practical life of Czech museums. The goal of its activities is to support innovative approaches and reflect the problems of Czech museum pedagogy, bring new impulses from abroad and systematically develop the discipline. ${ }^{4}$ From the above-mentioned facts follows that an inevitable part of the long-time activity of the Methodical Centre must be not only the attention paid to realisation of pilot projects and conception of own methodical and research activity, but also further professional education of museum pedagogues. ${ }^{5}$ The importance of educational activities organised by the Methodical Centre of Museum Pedagogy is closely related to transformations of the whole contemporary museum culture: "The respect to educational needs of visitors is one of important trends of contemporary museums, so that most of the innovations in the present-day museum culture are more or less 'museum-educational."'

\footnotetext{
3 Zápisy ze zasedání komise: Brno 7. 12. 2009. In Asociace muzeí a galerií České republiky [online]. [accessed 2018-06-01]. Available from www: $<$ http://www.cz-museums.cz/web/amg/organyamg/komise/komise-pro-praci-s-verejnosti-amuzejni-pedagogiku/zpravy-z-cinnosti-komise>

4 Metodické centrum muzejní pedagogiky [online] [accessed 2018-06-01]. Available from www: <http://www.mcmp.cz/>.

5 See DROBNÝ, Tomáš and Pavla VYKOUPILOVÁ. Místo Metodického centra muzejní pedagogiky v současných proměnách muzejní kultury. In Acta Musei Moraviae, series Scientiae sociales C III:1, 2018, pp. 65-71. In print.

6 ŠOBÁŇOVÁ, Petra. Edukační koncepce a strategie muzea v kontextu současné muzejní pedagogiky. In Muzejní edukátor: studijní materiál. 2017, pp. 39-73. Unpublished manuscript.
}

The course titled Basics of Museum Pedagogy was created in 2012. Two factors played an important role in its emergence. The first one was the independent existence of the Methodical Centre of Museum Pedagogy, which seceded in 2010 from the Children's Museum as a separate department of the Moravian Museum.The other factor was the elaboration of a long-term plan of activities of the Methodical Centre. Considerations on the medium-term priorities in activities of the Centre clearly showed that the museumpedagogical education of museum professionals counts among the most important tasks. ${ }^{7}$ It was necessary to establish a systematic frame for the educational museum-pedagogical activities and decide on the proportion and form of continuous and one-

-time educational programme. One-time educational actions represent highly operative, flexible tools responding to the identified needs of professional museum personnel. The continuous further professional education in culture, on the other hand, required to set a long-term objective, to describe the educational needs of the group for whom the educational offer is intended, and to choose the unequivocally defined educational content and form, that is, the form and extent of the educational offer. In 2011, when the preparation of the Basics of Museum Pedagogy course has started, it was also necessary to define the competence optimum for the profession of a museum pedagogue, which would be satisfied by the course. The starting point became the evaluation of the existing educational offer in the field of museology and museum education, where the potential of

\footnotetext{
7 See Plán činnosti: Střednědobá koncepce MCMP do r. 2016. In Metodické centrum muzejní pedagogiky [online]. [accessed 2018-06-01]. Available from www: < http://www.mcmp.cz/o-nas/plan-cinnosti/>.
}

a course of further education and the time possibilities of museum personnel became the limits. At that time, the Czech Association of Museums and Galleries organised for many years already the School of Museum Propaedeutics including an extension module, which contains a lecture in museum pedagogy. ${ }^{8}$ The basic course was in operation since 2002 , the extension module was implemented in $2006 .{ }^{9}$ An important contribution also resulted from a project by the Open Society Fund Prague titled Museum Gate Open, whose output also is an eponymous publication, and from the project Qualitative Innovation of Art Pedagogical Studies with published volumes School of Museum Pedagogy 1-7 (2007), realised by the Department of Art Education at the Faculty of Education of the Palacký University in Olomouc. ${ }^{10}$ This department prepared the studies in Museum and Gallery Pedagogy and offered them already earlier through the medium of the Centre for Lifelong Education at the Faculty of Education of the Palacký University

8 Škola muzejní propedeutiky. In Asociace muzeí a galerií České republiky [online]. [accessed 2018-06-01]. Available from www: <http://www.czmuseums.cz/web/amg/muzejni-propedeutika>. 9 BENČOVÁ, Monika. 15 let Školy muzejní propedeutiky 2002-2016. In Asociace muzeí a galerií České republiky [online]. 2017 [accessed 2018-06-01]. Available from www: <http:// www.cz-museums.cz/UserFiles/file/2017/SMP/ SMP_15\%20let_Vestnik_KOR\%20ANA_s\%20 tabulkami(1).pdf $>$.

10 „In 2006-2008, this department (Department of Art Education at the Faculty of Education of the Palacký University in Olomouc) attempted to integrate museum and gallery pedagogy into university education of art pedagogues with the help of its project Qualitative Innovation of Art Pedagogical Studies, which was kindly supported by the European Social Fund and the State Budget of the Czech Republic. “ ŠOBÁŇOVÁ, Petra. Škola muzejní pedagogiky 1. Poznámky k partnerství výtvarné a muzejní pedagogiky [online]. Olomouc: Univerzita Palackého v Olomouci, 2007, p. 9 [accessed 2018-06-01]. Available from www: $<$ http://kvv.upol.cz/files/pub/smp_01.pdf $>$. 
in Olomouc. ${ }^{11}$ Museological and museum-pedagogical education were offered within the scope of university study programmes ${ }^{12}$ at the Masaryk University in Brno, ${ }^{13}$ Silesian University in Opava ${ }^{14}$ and Palacký University in Olomouc. ${ }^{15}$ The Brno museology already had a long tradition and museum pedagogy was implemented into the basic curriculum of Master's degree museology studies, elaborated by Z. Z. Stránský in

11 ŠOBÁŇOVÁ, Petra. Muzejní a galerijní pedagogika a její zastoupení na českých univerzitách. In Actamusealia - suplementa 2013/1 Sborník př́spěvků z konference Muzeum a škola aneb Aby věci promluvily, 20. až 22. března 2013. Zlín: Muzeum jihovýchodní Moravy ve Zlíně, 2013, p. 12 .

12 For information about the state of education in museum pedagogy at universities at the beginning of the past decade see KRAJÍČKOVÁ, Lenka. K problematice vzdělávání v oblasti muzejní pedagogiky. Brno: Masarykova univerzita, Filozofická fakulta, Ustav archeologie a muzeologie, 2002, pp. 62-68. Master's thesis.

Supervisor Mgr. Pavel Holman.

13 See JAGOŠOVÁ, Lucie and Lenka

MRÁZOVÁ. Tradition of museum pedagogy in the Czech Republic and the role of Brno museology in its development. Museologica Brunensia [online]. 2015, vol. 4, no. 2, pp. 56-64 [accessed 2018-06-01]. Available from www: <https://digilib.phil.muni.cz/ bitstream/handle/11222.digilib/134749/2 MuseologicaBrunensia_4-2015-2_11. pdf? sequence $=1>$.

14 Věra Tomolová said about the museology studies: "Museum pedagogy is mainly given attention in specialised seminars on museum presentation with practical outcomes in the form of seminar essays and Bachelor's theses. "TOMOLOVÁ, Věra. Muzeum - výchova, vzdělávání, učení. Muzejní pedagogika ve výuce muzeologie na Slezské univerzitě. In Muzeum a vzdělávací systém $v$ České republice: sborník př́spěvků: $V$. Celorepublikové kolokvium na aktuální téma českého muzejnictví. Praha: Asociace muzeí a galerií České republiky, 2010, p. 34

15 The Department of Art Education of the Palacký University in Olomouc gained accreditation in 2012 and the first students began to study museum and gallery pedagogy in the academic year 2013/2014. See 2/ Katedra výtvarné výchovy, note No. 2, p. 23. MYSLIVEČKOVÁ, Hana and Petra ŠOBÁŇOVÁ (eds.). Vnímání, tvorba, komunikace. Olomouc: Univerzita Palackého v Olomouci, Pedagogická fakulta, Katedra výtvarné výchovy, 2014, pp. 9-23.
1994. ${ }^{16}$ The concept of studies proceeded in many regards from the curriculum of postgraduate museology studies, which already in the academic year 1971/72 included the Educational Function of Museum Communication course, and in 1981/82 the Educational Function of Museums course was implemented. ${ }^{17}$ The way to museum education at the Faculty of Education of the Masaryk University led through the Department of Art: "In 1998, for the first time in the Czech Republic, the curricula of this school included the course titled 'Mediation of Art'."18 But Horáček concludes: "In the late 1990s, however, the question still remains open how the education of museum and gallery pedagogues will develop in the nationwide context."19 The field of study titled Gallery Pedagogy and Mediation of Art appeared at the Brno Faculty of Education since the academic year $2009 / 2010$ as a new study programme within the follow-up Master's studies in secondary school teaching. ${ }^{20}$ The

16 MRÁZOVÁ, Lenka and Lucie JAGOŠOVÁ Obsahové proměny kurikula brněnské muzeologie v letech 1964-2014. Museologica Brunensia [online]. 2014, vol. 3, no. 2, pp. 28-42 [accessed 2018-06-01]. Available from www: < https://digilib.phil.muni.cz/ bitstream/handle/11222.digilib/133109/2 MuseologicaBrunensia 3-2014-2_6. pdf?sequence $=1>$; cf. PODBORSKÝ, Vladimír. Výuka muzeologie na Masarykově univerzitě. In Muzealizace $v$ soudobé společnosti a poslání muzeologie/Musealization in contemporary society and role of museology. Sborník ze sympozia s mezinárodní účastí pořádaného při př́ležitosti životního jubilee tvưrce brněnské muzeologické školy Zbyňka Z. Stránského/Anthology from symposium with foreign participation in the occasion of anniversary of the founder of the Brno museology school Zbyněk Z. Stránský. Praha: Asociace muzeî a galerií České republiky, 2008, p. 18.

17 See note 16 , Tab. 2, p. 33.

18 HORÁČEK, Radek. Galerijní animace a zprostředkování umění. Brno: CERM, 1998, p. 103.

19 Ibid.

20 STUCHLÍKOVÁ, Alice. Profese galerijního pedagoga [online]. Brno: Masarykova univerzita, Pedagogická fakulta, Katedra výtvarné výchovy, 2012, pp. 61-62 [accessed 2018-06-01] Dissertation thesis. Supervisor Prof.PaedDr. Radek Horáček, Ph.D. Available from www: $<$ https://is.muni.cz/th/jpt3e/Alice_Stuchlikova dizertace_2012.pdf $>$. curriculum of museum pedagogues is defined in the outputs of ICOM (International Council of Museums). In 2008, a compendium was elaborated titled Museum Professions - A European Frame of Reference, edited by Angelika Ruge, chairwoman of ICTOP (International Committee for the Training of Personnel). This document features on p. 24 the scope of employment of a Managerof the education and visitor service, and on p. 25 of an Education and visitor service officer. ${ }^{21}$ One year later the Smithsonian Center for Education and Museum Studies updated the curricula published in ICOM Curricula Guidelines for Museum Professional Development, which define the competences of individual professions. Part IV. titled Public Programming Competencies contains education and mediation. ${ }^{22}$

Because at that time the profession of a museum pedagogue was not yet included in the legislative document Catalogue of Occupations, ${ }^{23}$ it was necessary to consider the scope of employment in professions 2.14.21 Production, Programme and Culture-Educational Worker, 2.16.04 Leisure Time Pedagogue

21 RUGE, Angelika (ed.). Museum Professions A European Frame of Reference [online]. Paris: International Council of Museums, ICTOP, 2008 [accessed 2018-06-01]. Available from www: $<$ http://icom.museum/fileadmin/user_upload/ pdf/professions/frame_of_reference_2008.pdf $>$.

22 ICOM Curricula Guidelines for Museum Professional Development [online]. Smithsonian Center for Education and Museum Studies, Updated 28 August 2009, pp. 6-7 [accessed 2018-06-01]. Available from www: <http://icom museum/fileadmin/user upload/pdf/professions/ curricula_eng.pdf $>$.

23 2.04.32 Educator in Culture was included into the Catalogue of Occupations on 1 January 2018. See Nařízení vlády ze dne 6 . listopadu 2017, kterým se mění nařízení vlády č. 222/2010 Sb. o katalogu prací ve veřejných službách a správě, nařízení vlády č. 302/2014 Sb., o katalogu správních činností, a nařízení vlády č. 104/2005 Sb., kterým se stanoví katalog činností

v bezpečnostních sborech, ve znění pozdějších předpisů. Předpis č. 399/2017 Sb. In Sbírka zákonů České republiky, 2017, částka 140, ze dne 30. 11. 2017. 
and 2.04.09 Guide, which were most frequently used in practice to describe the work of museum pedagogues. ${ }^{24}$

\section{Extension of theoretical base for museum pedagogy in the early 21 st century}

An important buttress to the basic theoretical knowledge became the specialised monographs and articles from the given discipline, whose production began to rapidly increase since the first decade of the 21st century. ${ }^{25}$ Museum pedagogy: Methodological and didactic aspects of museum education (2010), Archaeology and museology (2005), Children's Museum. Educational phenomenon for the 21st century (2004), Introduction to museum practice. Learning texts for the basic course of the School of Museum Propaedeutics by the Czech Association of Museums and Galleries (2010), Outlines of museology for art historians (2002), Topical questions of art mediation. Theory and practice of gallery pedagogy, visual culture and art education (2007), Inspiration of museum pedagogy 1 (2010), or from among the older works a key writing dedicated to gallery pedagogy: Gallery animation and mediation of art (1998). From the foreign production we must mention at least the following works: The Educational Role of the Museum (1999), The Manual of Museum Learning (2007), Museum Educator's Handbook (2011). From the field of pedagogical sciences the basic sources were used, whose

\footnotetext{
24 See note 12

25 Lenka Krajíčková (Mrázová) in her 2002 diploma thesis On the problem of education in the field of museum pedagogy relates: „The problem of museum pedagogy, all the more of the teaching in this field, remains so far almost neglected in the Czech professional literature and similar also is the case with journal articles." (KRAJÍČKOVÁ, Lenka. K problematice vzdělávání $v$ oblasti muzejní pedagogiky. Brno: Masarykova univerzita, Filozofická fakulta, Ústav archeologie a muzeologie, 2002, p. 8. Master's thesis. Supervisor Mgr. Pavel Holman.)
}

focal points are related to the practical and theoretical problems of museum education: Teaching methods (2003), General didactics (2007), Interest education of adults (2009), School didactics (2002), Andragogy - theoretical foundations (2003), Chapters from the theory and practice of adult education (2009). Museum pedagogy overlaps with other disciplines of social sciences and humanities. Worth mentioning is, for example, the museum presentation, marketing and communication. Great support to the creation of the course came from the works Marketing of cultural heritage and art (2008) and Marketing and management of museums and monuments (2005).

\section{Objectives, content and form of the Basics of Museum Pedagogy course}

The offer of museum-pedagogical education for the museum personnel within the scope of the Basics of Museum Pedagogy course had to meet other requirements which appeared to be inevitable, in order to enable real achievement of the goal defined as follows: qualification enhancement under the condition of time and cost accessibility and particularly further practical applicability of the acquired knowledge and skills. The museum course was therefore designed as a two-semester teaching with nine lessons, one of them held in permanent and temporary museum exhibitions, where each lesson must be taught within a single working day.

The teaching held in permanent museum exhibitions has a practical character. The timetable respected the needs of participants who commuted from all over the Czech Republic and had to be regularly excused from work. The lessons are always held on Mondays. It was necessary to cope with considerable limitations, which result from the above-mentioned temporal frame. First of all, to adapt the content of teaching in individual lessons in order to secure the minimum of basic knowledge which can establish the foundations for further teaching, so that the extent of education creates a meaningful unit. With regard to this limitation, possible contentual and thematic overlaps of individual lessons or, the other way round, "white spaces" and incoherence, it was necessary to consider the reasonable continuity of lectures thoroughly and in detail with each lecturer. The last, tenth, learning session is dedicated to presentation of final student papers in the form of a colloquium. In order to obtain the certificate on completion of the course it is necessary not only to attend the sufficient number of lectures (60\%) but also to meet the requirements of elaboration and presentation of the final paper. This form was chosen instead of a mere examination of theoretical knowledge. The acquired competences of a museum pedagogue will be much better reflected in the application of acquired theoretical knowledge in the creative approach inevitable for elaboration of the concept of a museum-educational programme, or for its analysis and subsequent presentation before a commission and classmates.

At the start of preparation of an educational offer it is most important to define the target group for whom the product is intended, and the educational goals. Also important are practical aspects, which were already described above. The aim of the course is to prepare museum educators who are able to develop by themselves and to orient themselves in current situation in the discipline and in other topical trends of museum presentation. The educational programme has slightly changed in the course of time and the 
curriculum finally stabilised with following lectures: Basics of general pedagogy, development of museum education, where the lecturer doc. PhDr. Vladimír Jůva, CSc. jun. was replaced after two years by Mgr. Dagmar Hamalová, Introduction to museology, which is taught by Mgr. Pavel Holman, Education strategy of museums, lectured by doc. Mgr. Petra Šobáňová, Ph.D., Exhibition didactics, worksheets, secured by Mgr. et Bc. LenkaMrázová, Activating methods in museum pedagogy is a practical lecture, which is taught by Mgr. et Bc. LenkaMrázová and Mgr. et MgA. Barbora Svátková, Ph.D. in the Brno City Museum. The lecture Visitors with special educational needs is held by Mgr. Lucie Jagošová, DiS., Adult education and seniors in museums is taught by PhDr. Michal Šerák, Ph.D., Psychological aspects of museum education is taught by Mgr. Lucie Jagošová, DiS. and finally the Communication, marketing and $P R$ in museums is lectured by PhDr. Jan Dolák, Ph.D. The lecture Cognitive skills and their transformations in the course of ontogenesis held by PhDr. Denisa Denglerová, Ph.D. was implemented in the academic year $2014 / 2015$. Since the next year it was replaced by the lecture Psychological aspects of museum education taught by Mgr. Lucie Jagošová, DiS., and the lecture Art and gallery pedagogy, held by Mgr. et Bc. Alice Stuchlíková, Ph.D., was removed from the curriculum. The total number of lectures thus again decreased to nine, which eliminated the necessity to hold either two lectures within one month, or shift the final colloquium with defence of graduates' papers to July.

\section{Evaluation of the Basics of Museum Pedagogy course}

The above-mentioned curriculum and its minor changes resulted from a search for the optimal level of knowledge and skills of museum pedagogues, which can be offered within the scope of further professional education. In 2013 and 2014, two inquiries were carried out with the aim to enhance the quality of the course. After the first year, the evaluation by course participants was confronted with observations made by employees of the Methodical Centre during their inspection. The goal was to provide feedback to lecturers and remedy the shortcomings detected in the first run of studies. The evaluation forms in 2013 and 2014 were different. While the inquiry based on the first questionnaire was intended to ascertain the views in a wider context of the whole realisation of a new educational product, the second inquiry was already targeted at evaluation of individual lessons and presentation level of the lecturers involved. Both of the evaluation questionnaires were prepared and the inquiry was evaluated by Mgr. et Bc. Soňa Mertová.

The outcomes of the first inquiry (academic year 2012/2013) were not only inspiring for possible adjustments and improvements of the course, but provided a positive response to the prepared content and form of education. Fourteen out of seventeen participants $(82.35 \%)$ felt that the course completely or for the most part met their expectations, and the same number of participants wrote that the course was fully or mostly beneficial to their professional development. The time allocation for individual lessons of the course was considered optimal by thirteen informants (76.47 \%) and sufficient by four informants $(23.53 \%)$. Several participants critically remarked that the course is too theoretical and they demanded a better interconnection with practice.
The accomplished inquiries and the evaluation of satisfaction of course attendants via personal interviews initiated not only adjustments of the topics taught but also addition of the lecture Cognitive skills and their transformations in the course of ontogenesis in the academic year $2013 / 2014$. One year later this lecture was removed from the curriculum and replaced by Psychological aspects of museum education, and the Art and gallery pedagogy was removed. Another finding, which followed from inquiries and interviews with course attendants and pointed to an unnecessarily high amount of theoretical information, also had to be considered. With regard to this reflection, the lecturers endeavoured to change as much as possible the form of education to make it more interactive and interlinking the theoretical knowledge with practical experiences. The evaluation also noticed that some of the course attendants were graduates from museology studies or art pedagogy studies with specialisation in gallery presentation, so that the basic knowledge of the introduction to museology, basics of didactics or exhibition didactics did not bring anything new to them. Nevertheless, to most of the course attendants this teaching was absolutely inevitable, even though many of them were not aware of this fact. In some of the final papers and presentations from the first year of studies appeared the purely "practical" approach, which proceeded from the idea that museum pedagogy is only a question of practical realisation of "accompanying educational programmes" in museum exhibitions or only one of the existing possibilities of how to extend the cultural impact of collection-building institutions. And it is necessary to mention that until recently some members of the museum community still 


\begin{tabular}{|c|c|c|c|}
\hline LECTURE TITLE & $\begin{array}{l}\text { AVERAGE GRADE } \\
\text { (1-5 like at school) }\end{array}$ & MAJOR BENEFIT* & $\begin{array}{l}\text { MINIMUM } \\
\text { BENEFIT** }\end{array}$ \\
\hline 1. Activating methods in museums and galleries & 1.17 & 12 & - \\
\hline 2. Visitors with special educational needs & 1.40 & 8 & - \\
\hline 3. Exhibition didactics & 1.46 & 7 & - \\
\hline 4. Introduction to museum pedagogy, museum and school & 1.50 & 7 & - \\
\hline 5. Adult education and seniors in museums & 1.58 & 4 & 2 \\
\hline 6. Introduction to museology & 1.84 & 3 & 3 \\
\hline 7. Communication, marketing and $P R$ in museums & 2.00 & 2 & 1 \\
\hline 8. Basics of general pedagogy, development of museum education & 2.14 & 2 & 4 \\
\hline 9. Art and gallery pedagogy & 2.55 & 3 & 4 \\
\hline
\end{tabular}

* the number expresses how many times the participants evaluated a lesson as the most beneficial

$* *$ the number expresses how many times the participants evaluated a lesson as the least beneficial

Tab. 1: Evaluation of individual lessons of the course in the academic year 2012/2013, where the lessons were evaluated by 17 out of 24 course attendants (elaborated by Mgr. et Bc. Soňa Mertová)

adhered to the idea that museum pedagogy basically overlapped with "accompanying educational programmes" provided by lecturers in the form of a commented tour. The chasm separating theoretical knowledge from the Czech museum practice is generally expressed in the inability to properly identify the educational needs of the given target group, in erroneous use of methods and forms of education and incompetence in defining specific educational goals of the prepared form of education. The "practical" approach leads to the blind alley of repeating successful forms of the existing educational programmes and lacks any innovative dimension. The theoretical part of teaching had to be adjusted so that all participants will understand its relation to practical questions which a museum pedagogue must solve every day at work. The evaluation also contributed to better time arrangement of the teaching stuff in several lecturers. In the other cases it led to more active form of involvement of the course attendants in the teaching and pointed herewith to the effectiveness of the social aspect of learning.

\section{Significance of the Basics of Museum Pedagogy course and its wider reflections}

Regarding the mission of the Methodical Centre of Museum Pedagogy, which should accommodate the needs of professional museum personnel in the field of museum education, it was necessary to secure that the Basics of Museum Pedagogy is a wide open and low-threshold course. Herewith it differs from the academic forerunners of extension studies, or seminars whose prerequisite is the completed university education in related disciplines, such as museology or art education. A part of older museum workers oriented on the work with public and mediation of collections did not achieve university education. In the case of curators, university education already is a prerequisite, but the relevant expertise exceptionally also occurs together with museology or pedagogy studies. The course emerged in a time when the positions of museum educators were established as standard in regional museums and mid-sized museums, whereas large museums already had adequately specialised departments in their structure. However, these institutions also fundamentally changed the content and methods of work in departments which earlier only provided for lecturing and guiding services or associated the custodians. The Basics of Museum Pedagogy course can be a significant help for small museums and their educators, who are working with public only as a part of their cumulated position, among a few professional workers whom such museums can afford to pay. The later implementation of a fee therefore was not intended to reduce the number of possible students, but it only represented a disciplinary provision to rule out chronic absentees and insufficiently motivated applicants, who often do not complete the course and occupy in vain the places of others. The capacity of the course was given 
Morzsshe zemsht muzeum Metodiche rentrum muzejni pedogogikys podporsu Ministerstiva hultury to plipravito pro stiwajió procovinky muzei a galtery

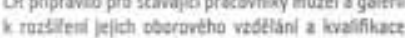
herz

\section{Základy \\ muzejini pedagogiky}

\author{
Pragran burn. \\ Uved do mareciagie

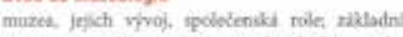

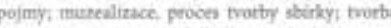 \\ wistav - proseny, scetnik, libretor, podminky nysta \\ wowisi púedrotta - toplota, swetlo atps nové trendy

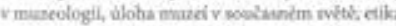

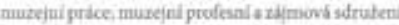

\section{Zukdady obeche pedayegiky, wivol musejini} toukece

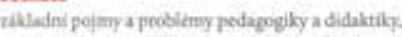

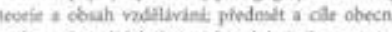

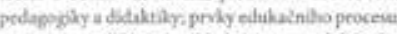

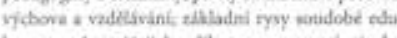

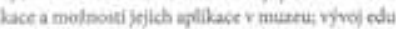
katni funkise mustah a vanik mesceini pedagegiky;

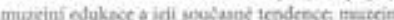

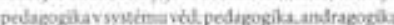

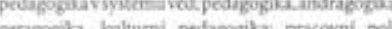
gerapogia, kaltumi pedapogika; pracosnil pole anciace muejni pedagogiky a detadych mared
Ovad to murejai pedagagiky, mureum a thati

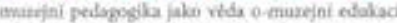

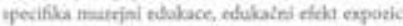

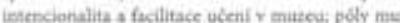

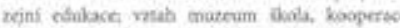

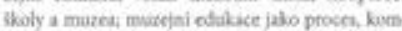
pooenty muzejui elakace - formy. mietody a die muteint pedogogichych aliwit: vadelivad potetik murzea: finze plibontini elukatnibo poogranta. jetio strultura a pliprava

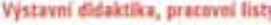

pourealizatai procesy we vatahy ke rosilivacin

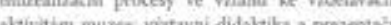

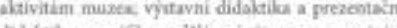

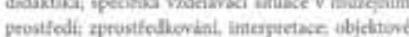

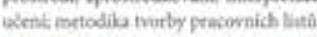

Akttvitujiti metody v mutajai petegegite

klavidat vyukové mefody a jefich vazha na muxein pedagogicke doptowodne peograssy altiviruilis A bampiexni wyukove metody, iefich opodatameds

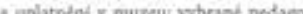

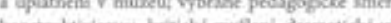

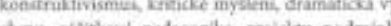

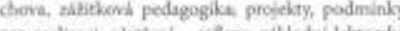

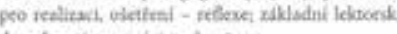

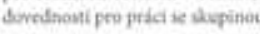

\section{Vitvarni a gaierijni pedagogiha}

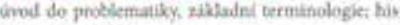

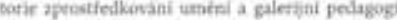

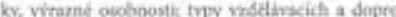

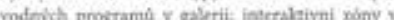
vingen program

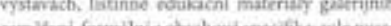

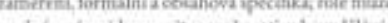

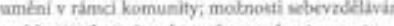
voblasti galeniji pedagogiky, profeani organirace

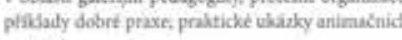
poutupè
Vredeliwand despelivich a seniali v emaxen ndeagogika, dospat jabo Ghatnik vedeliván apecifika vadetheini dooptyych, formilini, nedor.

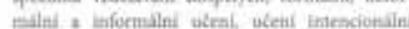

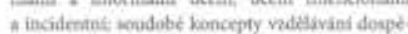

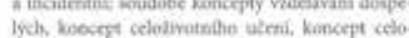

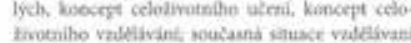

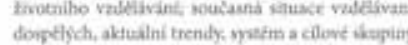
vadelswisi dospelych; kerontagngila, demograbc

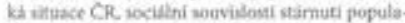

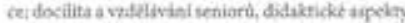

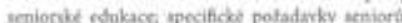

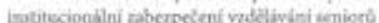

\section{Múvitërnid se spedibinimi vzdthivacini} potfetam

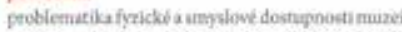

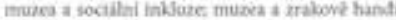

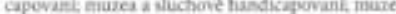

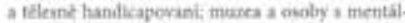
di mandac, pychickym onemocroenimi musea

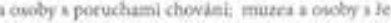

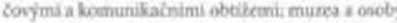

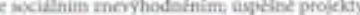

\section{Komunikace, erarketing a Pag y nurtr:}

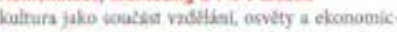

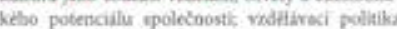

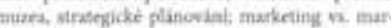
ceting kulhary, porice marketingu $x$ kulturni mati. vec, proces komunikact, terming identita instity. e, bodovini imags; media rdations, PR a medialini partnerivit komusibuce a propugace, varbs ma ad

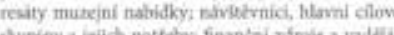
supetry a kich potetby: financsi adroje a vadel.

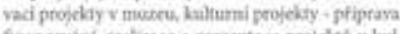

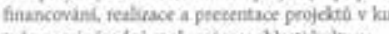
tute, merinirodni spolheprace r oblesti kuthury

Fig. 1: The 2012 leaflet of the Basics of Museum Pedagogy course with brief description of individual lectures

Morayské zemské migeam Metodirké centne muteini pedagagiky s padporou Ministestiva kul tury $C R$ phipravila pro stavalid precovniky muze à gaterii $k$ rozsifieni jejich obarovétho vadetán a livalfikate kurc

\section{Základy muzejin pedagogiky}

Progras hurtu:

Zaklady abecnt pedagagliky, wwoj murejei

edukate

zaldatni pedagogidié poimy, edubace vichova.

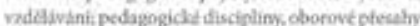

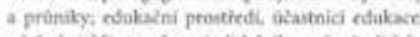

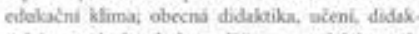

ticle metody, hurikukums dejing a soudobé trendy

mustini pedapogiky; evaluace muxejintpedapogir-

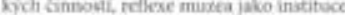

\section{Ovad do mureologie}

mutes, jejich vyvoj, apoletendal role zakladini pojums: maineslinace, proces twarby sbirky: twarbu

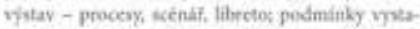
woini piedmino - tepiota, swetto atp: nowé trendy

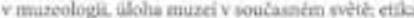

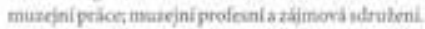

Edulatui strategie murea

didakticket sipekty musejini eduace (Sorm;, metody a clic murzejnè pedagogickych altmit; cilone supiny muxcjei cdubace, problem pliknovini cdes.

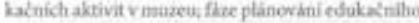

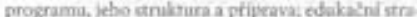
ttreje murzs doporviené sppeksy ptinewini (dis.

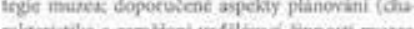

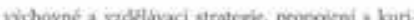

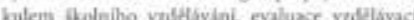
cienosti muzea); vize mexas a jeho podini

Vystavni didaktila, pracovni listy

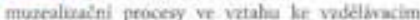
aktivitam meazex: vigtarni didaktila a prezentazni

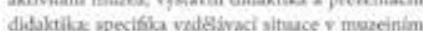
prostfedf: apcontifodhavini, isterpretace objidsove wienit metodila trorthy pracompica lintô

Ahtikitu|liti metody v murejini pedagogite

Wlasické vyulowe melody a iejich vaxba ma muxeipe? pedagogliche dopsowodine prouramy! altiviruikci

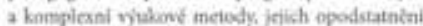
a uplatnéni $\mathrm{y}$ maxeu; prakticke ukjzky animacruich postopo pothedem marejni didakialy

Nivstienid se speriainimi vatelivadimi pettehami bariéry ve fyzicke a smydione dostupinnosti munet,

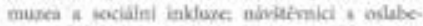

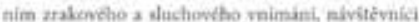
s omezenou mobilitiou, nivitedvnici s odshenim torumovtbo punivini nebo is pyyduckym neemocnènim, náshesnia s puruchami chovani, nil vistrnici s telonymi a kemmenikatnimi otnitemi,

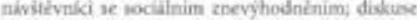
o ogetimilnim ptistupu ke spedalnima putliks mumi phiklady proiektâ

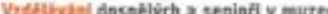

a koscept celotivotnitro sieni, Josply jaha ilast. nlk ectukiainich aktivit, andragoglicke koncepty

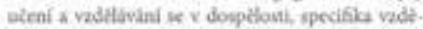
tavati donptlychy sookasna strace voddavani dospelych viCR, altudinin tresdy a problenuy, struikura

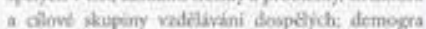

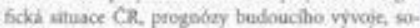

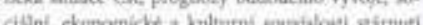

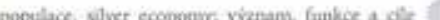
senionke edulace, molnonti a baricry vadiltivini ve tiptim veliw; fraicht a prochiclt wimuti a jeho viv ma valliavateinose seniorô, spesifika docdity

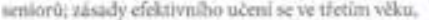
motivace iretiond $k$ utasts ns edakaknid alaivitich.

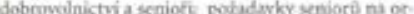

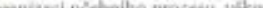
kampetence pracovnikî ve stitr seniondè etukace. upecifila komunilace se seniory

Paychaloglede aspekty muze|ni edulace jroces uleni $x$ hlediaka pedegogicke prycbologic:

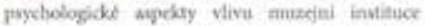

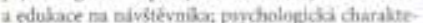
ristila jednotlivich dapin muzsjeilho publika; xiklady dusevni hygicny, prevease syndnamu vyho: teni

\section{a primureu}

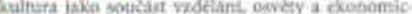

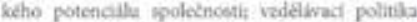

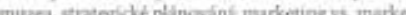

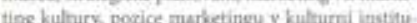

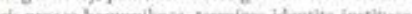

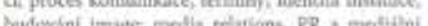

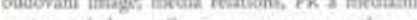

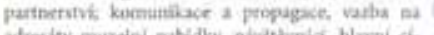

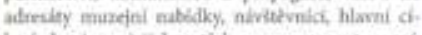
lowt skipiny a jejich potieby, managenent mueel, finanćnl zadroj= a vodeliveci projekty y muzeu, kul furni projekfy - ptiprava financovishi, realizace

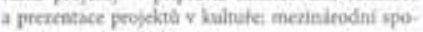
lupridce voblasti kultury

DOPOPOCOOPd

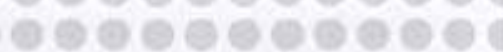
19000000000

Fig. 2: The 2016 leaflet of the Basics of Museum Pedagogy course with brief description of individual lectures 
by the dimensions of the classroom in the Methodical Centre, where most of the sessions are taking place and where a maximum of 24 places are available for use. The number of applicants exceeds this capacity every year, so that many of them accepted the position of substitutes to be able to commence their studies immediately when a place becomes vacant. The course was primarily targeted at museum personnel, but it was also open to interested persons from other memory institutions - libraries and institutes of heritage protection.

The impact of the course for museum educators must be perceived in a context wider than mere enhancement of professional qualification of individuals who successfully passed the studies. Also important is the positive evaluation of the possibility to encounter, discuss and exchange experience among course attendants and lecturers. The presentation and promotion of the course themselves represent an active entry into the discussion about the competence model of a museum educator. This fact can be materially evidenced by, for example, the printed advertising leaflets which contain an overview of lectures with brief description. For the needs of course attendants, individual lecturers elaborated learning texts which were published on the website of the Methodical Centre and in 2014 they occurred in the form of a printed volume titled Basics of museum pedagogy. Learning texts. The best of the graduates' final papers since 2013 have been published on the website of the Methodical Centre of Museum Pedagogy. ${ }^{26}$

After six runs, the Basics of Museum Pedagogy course is still attractive and the interest exceeded the acceptable number of admitted applicants every year. The implementation of a participation fee resulted in the past years in a distinct increase in the percentage of attendants who successfully passed the course (Tab. 1). The constitution of the professional qualification of museum educators and its approval in November $2016^{27}$

26 Kurz Základy muzejní pedagogiky 2012-2013. Nejúspěšnější závěrečné práce. In Metodické centrum muzejní pedagogiky [online]. [accessed 2018-06-01]. Available from www: <http:// www.mcmp.cz/vzdelavani/kurz-zakladymuzejni-pedagogiky/kurz-zaklady-muzejnipedagogiky-2012-2013/>.

27 Museum educator. In National Register of Qualifications [online]. [accessed 2018-06-01]. Available from www: <https://www. narodnikvalifikace.cz/en-us/qualification-1123>. opened to the Methodical Centre of Museum Pedagogy a new opportunity to fundamentally innovate the systematic offer of further professional education for museum pedagogues. The Moravian Museum applied for accreditation of the course for museum educators according to the accepted professional requalification, and in May 2018 it received a decree of accreditation from the Czech Ministry of Education, Youth and Sports. The teaching within this new accredited course should therefore start in September 2018 and this year will probably also finish the history of the existing unaccredited Basics of Museum Pedagogy course.

\begin{tabular}{|c|c|}
\hline ACADEMIC YEAR & $\begin{array}{c}\text { NUMBER OF } \\
\text { GRADUATES }\end{array}$ \\
\hline $2012 / 2013$ & 13 \\
\hline $2013 / 2014$ & 15 \\
\hline $2014 / 2015$ & 19 \\
\hline $2016 / 2017$ & 20 \\
\hline $2016 / 2017$ & 22 \\
\hline $2017 / 2018$ & 18 \\
\hline
\end{tabular}

Tab. 2: Total number of graduates from the Basics of Museum Pedagogy course 


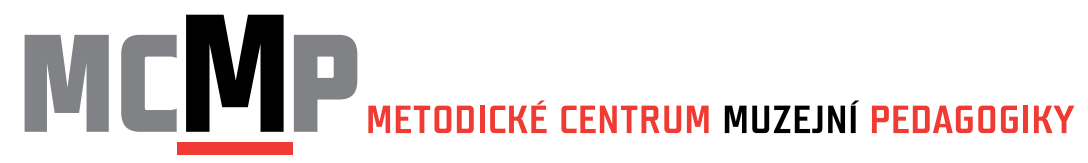

\section{EVALUATION QUESTIONNAIRE FOR THE BASICS OF MUSEUM PEDAGOGY COURSE ACADEMIC YEAR 2012/2013}

We kindly ask you to fill in this anonymous questionnaire. We would like to obtain information which helps us to evaluate the proceedings of the Basics of Museum Pedagogy course, its significance and benefits for the participants and we would also like to acquire impulses for its possible improvement in the future.

\section{TO WHAT EXTENT THE COURSE MET YOUR EXPECTATIONS?}

COMPLETELY FOR THE MOST PART HALFWAY ONLY IN SEVERAL REGARDS NOT AT ALL

2. TO WHAT EXTENT THE COURSE WAS BENEFICIAL TO YOUR PROFESSIONAL DEVELOPMENT? (mark out)

COMPLETELY FOR THE MOST PART HALFWAY ONLY IN SEVERAL REGARDS NOT AT ALL

SPACE FOR YOUR EXPLANATION:

3. NAME THE TOPIC/TOPICS WHICH ARE MOST USEFUL FOR YOUR PROFESSIONAL DEVELOPMENT can you specify the reasons?

1. Activating methods in museums and galleries

2. Visitors with special educational needs

3. Introduction to museum pedagogy, museum and school

4. Exhibition didactics

5. Adult education and seniors in museums

6. Introduction to museology

7. Art and gallery pedagogy

8. Communication, marketing and PR in museums

9. Basics of general pedagogy, development of museum education

4. NAME THE TOPIC/TOPICS WHICH ARE LEAST USEFUL FOR YOUR PROFESSIONAL DEVELOPMENT can you specify the reasons?

\section{WHICH OTHER TOPICS WOULD YOU WELCOME IN THE COURSE?}

6. YOUR OPINION ON THE TIME ALLOCATION FOR INDIVIDUAL TOPICS (mark out)

OPTIMAL SUFFICIENT INSUFFICIENT

7. Evaluate INDIVIDUAL LESSONS OF THE COURSE, which you have attended, with grades 1-5 (like at school; the lessons are ordered as they have taken place), and if you are interested, you can add verbal comment:

\section{WHO COVERED THE COSTS CONNECTED WITH YOUR PARTICIPATION IN THE COURSE (mark Out) EMPLOYER PARTICIPANT}

\section{DO YOU THINK THAT YOUR EMPLOYER CONSIDERS YOUR PARTICIPATION IN THE COURSE BENEFICIAL TO THE INSTITUTION?}

Supplement No. 1. Evaluation questionnaire for the Basics of Museum Pedagogy course in 2012/2013 (elaborated by Mgr. Bc. Soňa Mertová). 


\title{
EVALUATION OF INDIVIDUAL LESSONS OF THE BASICS OF MUSEUM PEDAGOGY COURSE BY ITS PARTICIPANTS (25 in total)
}

\author{
EVALUATION 1-5 LIKE AT SCHOOL, \\ WHERE THE MEAN IS THE RESULT
}

(note: only selected comments are shown which became the basis for corrections of the form and content of the course; the selection was made by Mgr. Tomáš Drobný)

Form of the lecture

1.47
Information content

1.76
Benefit of the lesson

\section{Doc. PhDr. Vladimír JU゚VA, CSc.} (evaluated by 17 out of 24 )

- I am relatively familiar with the content of the 1st lesson from the time of my studies. ...it was rather a knowledge refresh.

- I would welcome an interconnection of theory and practical issues.

- The lecture was well held, but it took an unnecessarily long time to discuss in special terms what we do in the museum practice.

\section{Mgr. Pavel HOLMAN}

(11 out of 20)

2.72

3.27

- It is a pity that the beneficial issues were not discussed until the final part of the lecture.

- The lecture, from my point of view, was not beneficial to the museum pedagogy course. In my opinion it did not represent any good introduction to the next lectures and most of us already attended similar lectures at the university.

Mgr. Petra ŠOBÁŇOVÁ, Ph.D.

(8 out of 17 )

1.50

1.25

1.37

- The seminar with Dr Šobáňová was highly beneficial, not only because we considered the creation of a strategy, but she also helped to weld our collective together, which was so far only possible during the lunchtime.

- It is a pity that there was not enough time to continue because it was interesting and motivating for our future activity.

PhDr. Denisa DENGLEROVÁ, Ph.D.

(6 out of 17)

Mgr. Lenka MRÁZOVÁ

(5 out of 18)

1.60

2.20

1.86

(13 out of 20$)$

a MRÁZOVÁ

Mgr. MgA. Barbora SVÁTKOVÁ, Ph.D.
1.80

2.20

- It was good to find out that the problems which bother me and the others are the same.

- The lecture was unfortunately longer than intended - and so were the discussion and our activities. It is a pity that we did not see the animated part of the programme...

\section{Mgr. Lenka MRÁZOVÁ}

substitute lesson (4 out of 8)*

1.00

1.25

1.25

\footnotetext{
*It is the evaluation of a substitute lesson which has taken place for reason of sickness of Mgr. MgA. B. Svátková, Ph.D.

PhDr. Michal ŠERÁK, Ph.D.

(9 out of 16)

1.22

1.66

1.33

- I think that adult education still is a little "taboo" to the museums, therefore I am grateful for this beneficial and interesting lecture.

- Dr.Šerák taught the seminar in a well-comprehensible and activating manner. I am very thankful that the lecture was held by somebody who said to us "where things stand".
} 
Mgr. Lucie JAGOŠOVÁ, DiS. (1 out of 12)

Mgr. Alice STUCHLÍKOVÁ, Ph.D. (3 out of 11)

PhDr. Jan DOLÁK, Ph.D. (5 out of 11)
1.00

2.00

3.00

3.00

1.4
1.00

3.00

1.2

Supplement No. 2. Evaluation of individual lessons of the Basics of Museum Pedagogy course in 2013/2014 (elaborated by Mgr. Bc. Soňa Mertová, edited by Mgr. Tomáš Drobný).

\section{LITERATURE AND SOURCES:}

BENČOVÁ, Monika. 15 let Školy muzejní propedeutiky 2002-2016. In Asociace muzeí a galerií České republiky [online]. 2017 [accessed 2018-06-01]. Available from www: <http://www.cz-museums. cz/UserFiles/file/2017/SMP/SMP_15\%20 let_Vestnik_KOR\%20ANA_s\%20 tabulkami(1).pdf $>$.

BENEŠ, Josef. Muzejní prezentace. Praha: Národní muzeum, 1981.

BENEŠ, Milan. Andragogika: teoretické základy. Praha: Eurolex Bohemia, 2003. ISBN 80-86432-23-8.

BRABCOVÁ, Alexandra (ed.). Brána muzea otevřená: průvodce na cestě muzea $k$ lidem a lidí do muzea. Náchod: Juko; Praha: Nadace Open Society Fund, 2003. ISBN 80-86213-28-5.

BURIÁNKOVÁ, Michaela, Anna KOMÁRKOVÁ and František ŠEBEK (eds.). Úvod do muzejní praxe. Učební texty základního kurzu Školy muzejní propedeutiky Asociace muzeí a galerií České republiky. Praha: Asociace muzeí a galerií České republiky, 2010. ISBN 978-80-86611-40-2.

DROBNÝ, Tomáš and Pavla VYKOUPILOVÁ. Místo Metodického centra muzejní pedagogiky v současných proměnách muzejní kultury. In Acta Musei Moraviae, series Scientiae sociales C III:1, 2018, pp. 65-71. ISSN 0323-0570. In print.

HOOPER-GREENHILL, Eilean. The Educational Role of the Museum. London, New York: Routledge, 1994. ISBN 0-415-11287-7.

HORÁČEK, Radek and Jan ZÁLEŠÁK. Aktuální otázky zprostředkování umění: teorie a praxe galerijní pedagogiky, vizuální kultura a výtvarná výchova.
Brno: Masarykova univerzita, 2007 [accessed 2018-06-01]. Available from www: <http://www.digitalniknihovna. cz/mzk/uuid/uuid:a18fb720-cfc7-11e5-ab98-005056827e52>. ISBN 978-80-210-4371-8.

HORÁČEK, Radek. Galerijní animace a zprostředkování umění. Brno: CERM, 1998. ISBN 80-7204-084-7.

ICOM Curricula Guidelines for Museum Professional Development [online]. Smithsonian Center for Education and Museum Studies, Updated 28 August 2009 [accessed 2018-06-01]. Available from www: <http://icom.museum/ fileadmin/user_upload/pdf/professions/ curricula_eng.pdf $>$.

JAGOŠOVÁ Lucie and Lenka MRÁZOVÁ. Tradition of museum pedagogy in the Czech Republic and the role of Brno museology in its development. Museologica Brunensia [online]. 2015, vol. 4, no. 2, pp. 56-64 [accessed 2018-06-01]. Available from www: <https://digilib.phil.muni.cz/bitstream/ handle/11222.digilib/134749/2_ MuseologicaBrunensia_4-2015-2_11. pdf? sequence $=1>$.

JAGOŠOVÁ, Lucie and Otakar KIRSCH et al. Muzejní profese a veřejnost 1. Nástin historie a současnosti vzájemných vztahů muzea a jejich publika [online]. Brno: Masarykova univerzita, Filozofická fakulta, Ústav archeologie a muzeologie, 2016 [accessed 2018-06-01]. Available from www: <http://archeo-muzeo. phil.muni.cz/media/3056324/muzejni_ profese_a_verejnost.pdf $>$.

JAGOŠOVÁ, Lucie, Vladimír JŮVA and Lenka MRÁZOVÁ. Muzejní pedagogika: Metodologické a didaktické aspekty muzejní edukace. Brno: Paido, 2010. ISBN 978-80-7315-207-9.

JOHNOVÁ, Radka. Marketing kulturního dědictví a umění. 1st ed. Praha: Grada Publishing, 2008. ISBN 978-80-247-2724-0.

JŮVA, Vladimír. Dětské muzeum: edukační fenomén pro 21. století. Brno: Paido, 2004. ISBN 80-7315-090-5.

KALHOUS, Zdeněk and Otto OBST et al. Školní didaktika. Praha: Portál, 2002. ISBN 80-7178-253-X.

KESNER, Ladislav. Marketing a management muzeí a památek. 1st ed. Praha: Grada, 2005. ISBN 80-247-1104-4.

KIRSCH, Otakar and Lucie JAGOŠOVÁ. Vývoj Lektorátu muzejnictví 1922-1951. Devadesát let od počátků univerzitního vzdělávání muzejníků v českých zemích. Muzeum: muzejní a vlastivědná práce, 2013, vol. 51, no. 1, pp. 3-16. ISSN 1803-0386.

KRAJÍČKOVÁ [MRÁZOVÁ], Lenka. $K$ problematice vzdělávání $v$ oblasti muzejní pedagogiky. Brno: Masarykova univerzita, Filozofická fakulta, Ústav archeologie a muzeologie, 2002. Master's thesis. Supervisor Mgr. Pavel Holman.

Kurz Základy muzejní pedagogiky 20122013: Nejúspěšnější závěrečné práce. In Metodické centrum muzejní pedagogiky [online]. [accessed 2018-06-01]. Available from www: <http://www. mcmp.cz/vzdelavani/kurz-zaklady-muzejni-pedagogiky/kurz-zaklady-muzejni-pedagogiky-2012-2013/>.

LORD, Barry (ed.). The Manual of Museum Learning. Plymouth: AltaMira Press, 2007. ISBN 978-0-7591-0971-1.

Metodické centrum muzejní pedagogiky [online]. [accessed 2018-06-01]. Available from www: <http://www. mcmp.cz/>. 
MRÁZOVÁ, Lenka and Lucie JAGOŠOVÁ. Obsahové proměny kurikula brněnské muzeologie v letech 1964-2014. Museologica Brunensia [online]. 2014, vol. 3, no. 2, pp. 28-42 [accessed 2018-06-01]. Available from www: <https://digilib.phil.muni.cz/bitstream/ handle/11222.digilib/133109/2_ MuseologicaBrunensia_3-2014-2_6. pdf? sequence $=1>$.

Museum educator. In National Register of Qualifications [online]. [accessed 2018-06-01]. Available from www: <https:// www.narodnikvalifikace.cz/en-us/ qualification-1123>.

Muzejní propedeutika: rozvrh základního kurzu. In Asociace muzeí a galerií České republiky [online]. [accessed 2018-06-01]. Available from www: <http:// www.cz-museums.cz/web/amg/muzejnipropedeutika/zakladni-kurs/rozvrh-zakladniho-kursu>.

MYSLIVEČKOVÁ, Hana and Petra ŠOBÁŇOVÁ (eds.). Vnímání, tvorba, komunikace. Olomouc: Univerzita Palackého v Olomouci, Pedagogická fakulta, Katedra výtvarné výchovy, 2014, pp. 9-23. ISBN 978-80-244-4196-2.

Nařízení vlády ze dne 6 . listopadu 2017, kterým se mění nařízení vlády č. 222/2010 Sb., o katalogu prací ve veřejných službách a správě, nařízení vlády č. 302/2014 Sb., o katalogu správních činností, a nařízení vlády č. 104/2005 Sb., kterým se stanoví katalog činností v bezpečnostních sborech, ve znění pozdějších předpisů. Předpis č. 399/2017 Sb. In Sbírka zákonů České republiky, 2017, částka 140, ze dne 30. 11. 2017.

Plán činnosti: Střednědobá koncepce MCMP do r. 2016. In Metodické centrum muzejní pedagogiky [online]. [accessed 2018-06-01]. Available from www: <http:// www.mcmp.cz/o-nas/plan-cinnosti/>.

PODBORSKÝ, Vladimír. Výuka muzeologie na Masarykově univerzitě. In Muzealizace $v$ soudobé společnosti a poslání muzeologie/Musealization in contemporary society and role of museology: Sborník ze sympozia s mezinárodní účastí pořádaného při př́ležitosti životního jubilea tvưrce brněnské muzeologické školy Zbyňka Z. Stránského/Anthology from symposium with foreign participation in the occasion of anniversary of the founder of the Brno museology school Zbyněk Z. Stránský. Praha: Asociace muzeí a galerií České republiky, 2008, pp. 14-26. ISBN 978-80-86611-28-0.

POLÁKOVÁ, Zdeňka et al. Inspiration muzejní pedagogiky 1. Brno: Moravské zemské muzeum, Dětské muzeum Centrum muzejní pedagogiky, 2010. ISBN 978-80-7028-361-5.

RUGE, Angelika (ed.). Museum Professions A European Frame of Reference [online]. Paris: International Council of Museums, ICTOP, 2008 [accessed 2018-06-01]. Available from www: <http://icom. museum/fileadmin/user_upload/pdf/ professions/frame_of_reference_2008. pdf $>$.

STRÁNSKÝ, Zbyněk Zbyslav. Archeologie a muzeologie. 1st ed. Brno: Masarykova univerzita, 2005. ISBN 80-210-3861-6.

STRÁNSKÝ, Zbyněk Zbyslav. Úvod do studia muzeologie. 2nd ed. Brno: Masarykova univerzita, 2000. ISBN 80-2710-1272-2.

STUCHLÍKOVÁ, Alice. Profese galerijního pedagoga [online]. Brno: Masarykova univerzita, Pedagogická fakulta, Katedra výtvarné výchovy, 2012 [accessed 2018-06-01]. Dissertation thesis. Supervisor Prof.PaedDr. Radek Horáček, Ph.D. Available from www: <https:// is.muni.cz/th/jpt3e/Alice_Stuchlikova_dizertace_2012.pdf $>$.

ŠERÁK, Michal. Zájmové vzdělávání dospělých. Praha: Portál, 2009. ISBN 978-80-7367-551-6.

ŠERÁK, Michal and Miroslava DVOŘÁKOVÁ. Kapitoly z teorie a praxe vzdělávání dospělých. Praha: Institut vzdělávání a poradenství ČZU v Praze, 2009. ISBN 978-80-213-2001-7.

Škola muzejní propedeutiky. In Asociace muzeí a galerií České republiky [online] [accessed 2018-06-01]. Available from www: <http://www.cz-museums.cz/ web/amg/muzejni-propedeutika $>$.

ŠOBÁŇOVÁ, Petra. Edukační koncepce a strategie muzea v kontextu současné muzejní pedagogiky. In Muzejní edukátor: studijní materiál. 2017, pp. 39-73. Unpublished manuscript.

ŠOBÁŇOVÁ, Petra. Muzejní a galerijní pedagogika a její zastoupení na českých univerzitách. In Actamusealia - suplementa 2013/1. Sborník př́spěvků z konference Muzeum a škola aneb Aby věci promluvily, 20. až 22.března 2013. Zlín: Muzeum jihovýchodní Moravy ve Zlíně, 2013, pp. 11-14. ISBN 978-80-8713028-5.

ŠOBÁŇOVÁ, Petra. Škola muzejní pedagogiky 1. Poznámky k partnerství výtvarné a muzejní pedagogiky [online]. Olomouc: Univerzita Palackého v Olomouci, 2007, p. 9 [accessed 2018-06-01]. Available from www: <http:// kvv.upol.cz/files/pub/smp_01.pdf $>$.

TALBOYS, Graeme K. Museum Educator's Handbook. 3rd ed. Burlington: Ashgate, 2011. ISBN 978-1-4094-0152-0.

TOMOLOVÁ, Věra. Muzeum - výchova, vzdělávání, učení. Muzejní pedagogika ve výuce muzeologie na Slezské univerzitě. In Muzeum a vzdělávací systém $v$ České republice: sborník přispěvků: V. Celorepublikové kolokvium na aktuální téma českého muzejnictví. Praha: Asociace muzeí a galerií České republiky, 2010, p. 34. ISBN 978-80-86611-39-6.

WAIDACHER, Friedrich. Príručka všeobecnej muzeológie. Bratislava: Slovenské národné múzeum, 1999. ISBN 3-205-77268-7.

Základy muzejní pedagogiky. Studijní texty. Brno: Moravské zemské muzeum, 2014. ISBN 978-80-7028-441-4.

Zápisy ze zasedání komise: Brno 7. 12. 2009. In Asociace muzeí a galerií České republiky [online]. [accessed 2018-06-01]. Available from www: <http:// www.cz-museums.cz/web/amg/organy-amg/komise/komise-pro-praci-s-verejnosti-a-muzejni-pedagogiku/ zpravy-z-cinnosti-komise $>$. 


\section{TOMÁŠ DROBNÝ}

Metodické centrum muzejn pedagogiky, Moravské zemské muzeum, Brno, Česká republika tdrobny@mzm.cz

He has long been concerned with protection and utilisation of the potential of cultural heritage and the significance of culture to present-day society. At the Masaryk University in Brno he graduated in the fields of history and archaeology (1995). He worked in various positions in museums, in organisation of state preservation of historical monuments and in the Department of Culture and Monument

Preservation at the Regional Office of South Moravian Region. Since 2011 he has been the head of the Methodical Centre of Museum Pedagogy in the Moravian Museum. He is author of the conception of the Basics of Museum Pedagogy course and since May 2018 he is guarantor of the approved accredited Museum Educator course in the Moravian Museum. In the field of museum pedagogy and museology he published the methodical writing Seniors in museums: Methodical materials (Drobný, Šerák 2016), he is author of methodical chapters Institutors and Sphere of Monuments in the methodical work Evaluation of innovations. Assessing the efficiency of public funds expended to secure quality and accessibility of public cultural services (2016), co-author of the chapter Museums and Galleries in the Methodical recommendation of the Ministry of Culture for volunteering in culture and art (Drobný, Vykoupilová 2015). He published a series of professional articles, e. g. Activities of the Methodical Centre of Museum Pedagogy in the field of artistic education (2018), Creation of collections of saintly relics as a part of representation of Charles IV. (2017), Museums and seniors (2016), Collections of saintly relics as a tool for representation of the statehood idea by Charles IV. (2016), Making a visit - mediation of communication in space and time (2015), Contemporary witnesses narrate and what the museums remember (2014), Cultural heritage and memory institutions from the viewpoint of museum pedagogy (2014).

Dlouhodobě se zabývá ochranou a využitím potenciálu kulturního dědictví a významem kultury v současné společnosti. $\mathrm{Na}$ Masarykově univerzitě v Brně vystudoval historii a archeologii (1995). Pracoval na různých pozicích v muzeu, v organizaci státní památkové péče a na odboru kultury a památkové péče Krajského úřadu Jihomoravského kraje. Od roku 2011 je vedoucím Metodického centra muzejní pedagogiky v Moravském zemském muzeu. Je autorem koncepce kurzu Základy muzejní pedagogiky a od května 2018 garantem schváleného akreditovaného kurzu muzejního edukátora v Moravském zemském muzeu.

V oboru muzejní pedagogiky a muzeologie publikoval metodiku Senioři v muzeu: metodický materiál (Drobný, Šerák 2016), je autorem kapitol Zřizovatelé a Památková oblast v metodice Hodnocení inovací. Posouzení efektivnosti vynaložených veřejných prostředků na zajištěni kvality a dostupnosti veřejných kulturních služeb (2016), spoluautorem kapitoly Muzea a galerie v Metodickém doporučení Ministerstva kultury pro dobrovolnictví v kultuře a umění (Drobný, Vykoupilová 2015). Publikoval řadu odborných článků, např. Aktivity Metodického centra muzejní pedagogiky na poli uměleckého vzdělávání (2018), Vytváření sbírek relikvií jako součásti reprezentace Karla IV. (2017), Muzea a senioři (2016), Sbírky relikvií nástrojem reprezentace ideje státnosti Karla IV. (2016), Na návštěvě zprostředkování komunikace v prostoru a čase (2015), Pamětníci vyprávějí a co pamatují muzea (2014), Kulturní dědictví a pamětové instituce $\mathrm{z}$ pohledu muzejní pedagogiky (2014).

\section{PAVLA VYKOUPILOVÁ}

Metodické centrum muzejní pedagogiky, Moravské zemské muzeum, Brno, Česká republika pvykoupilova@mzm.cz

She graduated in the Master's study fields Czech language and literature and Art education at the Faculty of Education of the Masaryk University in Brno. After having completed the university studies, she taught in several primary and secondary schools in Brno and then she worked as a lecturer in the Children's Museum of the Moravian Museum. Since 2009 she has been working in the Methodical Centre of Museum Pedagogy. She provides for administration of the web portal MCMP and MUZEOEDU. She participated in preparation of the accredited Museum Educator course in the Moravian Museum. She is co-author of the chapter Museums and Galleries in the Methodical recommendation of the Ministry of Culture for volunteering in culture and art. Her professional focus is laid on pilot educational projects for disadvantaged visitors and she published various texts, e. g. Museum-pedagogical work of MCMP with disadvantaged groups of visitors (2015). She is co-author of the paper Process of emergence of an accompanying educational programme as a reason for cooperation - reflection on 
a questionnaire survey (Mertová, Vykoupilová 2015).

Vystudovala magisterský studijní obor Český jazyk a literatura a Výtvarná výchova na Pedagogické fakultě Masarykovy univerzity v Brně. Po ukončení vysoké školy učila na několika brněnských základních a středních školách, poté pracovala jako lektorka v Dětském muzeu Moravského zemského muzea. Od roku 2009 působí v Metodickém centru muzejní pedagogiky.

Zajištuje administraci webového portálu MCMP a MUZEOEDU. Podílela se na př́ipravě akreditovaného kurzu muzejního edukátora v Moravském zemském muzeu. Je spoluautorkou kapitoly Muzea a galerie v Metodickém doporučení Ministerstva kultury pro dobrovolnictví v kultuře a umění. Specializuje se na pilotní edukační projekty pro znevýhodněné návštěvníky a publikovala texty např. Muzejně-pedagogická práce MCMP se znevýhodněnými skupinami návštěvníků (2015). Je spoluautorkou příspěvku Proces vzniku doprovodného edukačního programu jako di̊vod spolupráce reflexe dotazníkového šetření (Mertová, Vykoupilová 2015). 